\title{
Local Wisdoms on Luang Island, Southwest Moluccas, Indonesia and Its Implementation in Learning
}

\author{
Kalvin Karuna $^{(1)}$, Henderika Serpara ${ }^{(2)}$ \\ Universitas Pattimura, Indonesia \\ E-mail: (1)kievkaruna21@gmail.com
}

Received: 15 December 2020; Revised: 22 April 2021; Accepted: 5 May 2021

\begin{abstract}
Local wisdom included cultural patterns of interpretation of certain localities, pure values, and unwritten norms, which serve the social life of a community and environment to regulate. The head of the ethnic groups in the community makeup but worries that the local wisdom are in danger lost to go. This article describes the current state of local wisdom as a cultural pattern of interpretation on the Luang Island - Indonesia. In addition, the manners, customs, and traditions of the community on the island are observed and an interview with four teenagers and ahead of the community is performed. The results of the observation and the interview are then presented and analyzed. The analysis has shown the following: (a) there are several local wisdom, which the harmony of the life of the community on the Luang island and the environment build may, for example, "urgeni, te'wa, hrukwu mnyota, hlili mnyota, lyola" (b) the local wisdom has one long tradition in the community. However, this seems lost to go because of the way of life of the local population. As a result, the valuable wisdom is in a "culture shift" situation. The local wisdom should to be used in the classroom, so that students as young generation be sensitized and note taking this wisdom.
\end{abstract}

Keywords: local wisdom; cultural patterns of interpretation; community; teaching.

\section{INTRODUCTION}

"Lain ladang lain belalang, lain lubuk lain ikannya"- that is a well-known proverb in Indonesian, which can be equated with the English proverb "other countries, other customs". The saying is an appeal to solidarity for diversity. Unity in diversity is an important theme in Indonesia. The origin of this motto has its origin in the fact that Indonesia consists of 17,504 islands, 633 ethnics, and 34 provinces.

The different customs and traditions of an ethnically diverse group promote cultural pluralism, but lead often to misunderstandings. Therefore, these differences must be taken into account when it is dealing with members of other ethnical groups, because local wisdom becomes one of the media to solve the problem (Kurnianto,
2020).

This contribution busies themselves with the customs and domestic shrines on the Luang island, in Southwest Moluccas. This island belongs to a series of islands, the south-west of the capital of Maluku province is. The island is 317 nautical miles from the capital of the Moluccas Province, and 202 nautical miles north of Australia. The life on the island was by the so-called Kalwedo culture dominated harmonious.

The concept Kalwedo includes Hnyolilieta, a way of life, which is on the consideration for fellow human beings focused. By Hnyolilieta created different types of wisdom, the strengthening harmony, solidarity, and brotherhood in the community, for example, "Urgeni, te'wa, Lyola, hrukwu Myota, hlili mnyota". Local wisdom has one long tradition in the com- 
munity life on the island, because the inhabitants were not influenced by cultures of other ethnic groups in their existence and history of other islands.

The ideal togetherness in the community is nowadays under the pressure of globalization. There is now television, smartphones and visitors are coming from other regions. The superintendent or management of the ethnic group to Luang make consequently worry that local wisdom in danger of being lost. This is in some phenomena, such for example the reckless behavior of the younger generation against the older recognizable. But also in the way and manner as they each greet and the fact, that the habit to old people especially the old widow's foods donates. It is always more lost. This is observed and as the result of interview with Ms. Bathsheba Kaneti, who has a long culture on the island of Luang.

\section{Overview of Luang Island}

Luang is one of a series of islands bordering Australia to the south and East Timor to the west. The island has two villages, and can not be managed, are because the soil is only from bedrock and savannah. The main food of the inhabitants was grains such as corn, various types of beans, and also cassava and fresh fish. The groceries had to be bought on other neighboring islands, sometimes even in Ambon.

Nowadays the people of the island also consume rice, like the other Indonesian people. It takes three to four days to get to Ambon by sailing boat. Because of the situation, residents had to make efforts to build sailboats so that they could go to the other islands to sell their salted fish, sea cucumbers and seaweed, and to buy other groceries. Therefore they have to call on the inhabitants of the neighboring islands, to be brave sailors, since they had been sailing often to other islands and to their own culture on the other neighboring islands. This is due to cultural similarities between Luang Island and the neighboring islands, such as Sermata Island, Leti, Moa Lakor, and a part of Babar recognizable. In a conversation with $\mathrm{Mr}$. Kaary, ahead of a neighboring island, it was confirmed that the Luang Island has re- ceived recognition as an important cultural center from most of the inhabitants of other islands. The current handling of the islanders has changed with outsiders. Sailboats are no longer produced, one out of town rather with large ships. It may be noted are that the ships come once in the month to the island. Also, rise the range of goods, as well as the use of mobile phones and television, are increasing. The residents are now in a transition from traditional to a modern life.

Nowadays, young people have decided to emigrate for a study or work. There is still no firmed data on the number of young people, who are currently studying in Ambon, but it is estimated that it is about $1 \%$ of the 1267 inhabitants on the island. It is positively, but on the other hand, the young people have to worry losing their own cultural identity despite the contact with the narrative of modernization.

\section{Local Wisdom}

Syntactically, there is the phrase local wisdom from two words, namely locally and wisdom. The word local refers to a specific place, while wisdom as knowledge understood, is the one with experience gets. Therefore, it can be stated that local wisdom is a collection of knowledge that the one particular community has adopted traditionally. Local wisdom is called a worldview and knowledge that can be recognized as life strategies in a certain community, such as the way of problem-solving, including the problems in elementary education (Sugiyo et al, 2017).

Indonesian law referred to the local wisdom as applicable pure values in the life of a community, which as a regulation of community life function. (see UU. Nomor 32 Tahun 2009). According to the law, local wisdom contains pure life values as the basis for building community life in certain places. Former Minister of Environment of Indonesia defines local wisdom as knowledge, belief, understanding, habits, and etiquette that govern the life of the community in a particular place. The wisdom is from a generation to the next generation handed down and has lasting effects on the life of each generation (Keraf, 2010). Acoording to Keraf, local wisdom are ownership of a particular community. Thus, there 
is no individual wisdom. Local wisdom is also called traditional knowledge, which governs life and the relationship between man and nature, and has the function of local wisdom as a cultural filter or controls the introduced culture. This means that all foreign cultures have to be accepted through an adaptation process or acculturation. Based on these definitions, the conclusion can be drawn that local wisdom or local wisdom exists as a cultural pattern of interpretation in certain places. The values and norms serve to enhance the life of a community and their environment to regulate. The life of the community and its environment focuses on the same modes of action for a harmonious relationship between people on the one hand and between people and nature on the other hand.

\section{MATERIALS AND METHODS}

This contribution is descriptive research, which was performed above the island. The focus of this research was to examine the manners and customs of the community on the island. The manners and customs of the community are observed and an interview is also carried out with two chiefs or leaders of the ethnic group and four young people of the community. The dean and two young people have been living for the birth on the island, while the two other young people have been studying in Ambon. The result of the observation and the interviews is illustrated and analyzed following.

\section{RESULT AND DISCUSSION}

The analysis has the following result; (a) the residents have a lot of local wisdom for a long time. However, there is no indication of when these pearls of wisdom arose and who initiated them, (b) the local pearls of wisdom that cultivate the harmonious life of the community are among others "Urgeni, te'wa, Lyola, hrukwu myota, hlili mnyota".

Urgeni: bringing food to the neighbor or old widow. This is done by the residents who have just returned home from the trip to buy groceries from other islands. This wisdom is also known on other neighboring islands, for example on Moa Island.

$T e^{\prime} w a$ : bringing fresh fish or meat to the neighbor or certain people. The fish or meat is brought to the people who were not fished that day.

Lyola: donating money, animals, and building materials to relatives. They do this at a wedding, someone dies in a family, or when someone builds a house.

Hrukwu mnyota: Hrukwu is a container made of palm leaves. Such food is placed to store or transport.

Mnyota: contents of one container.

Hrukwu Mnyota: Food that is brought to relatives when there is a certain celebration, for example, a celebration on the occasion of a death or a house being built. Usually, the housewives come to help with the construction of a house or with the preparation of a party. The house owner or host prepares the food and drink, which he has not to buy, but he gets the food (fish, meat, cassava, corn, and rice) in the form of Hrukwu Myo$t a$. The relatives or neighbors bring that along. They also help by cooking and serving the food. The food should be brought in the day before. They also can help to prepare for the celebration.

Hlili Myota: Hlili is also a container made of palm leaves, or of wood, in which are one sirih (Piper betle) and Pinang (Latin: Areca catechu, engl. Betel nut), and sets into tobacco. Mnyota is the content of Hlili. Therefore, Hlili Myota is sirih (Piper betle) and Pinang (Latin: Areca catechu, Engl. Betel nut).

Hlili: is a symbol of the togetherness of women. After the preparation of the meal, the women sit down together and chew the sirih and pinang, (in Indonesian they say makan pinang). In this moment, they talk each other and have fun. Usually, the men smoke and the women chew sirih and pinang.

This local wisdom is also known on other neighboring islands, for example on the island of Moa. Instead of Hrukwu mnyota, people say lima mnyota (lima $=$ hand, it means what you bring with you).

In other provinces, for example, Gorontalo, north of Celebes Island, there is also such wisdom, that they called huyula (working together). In the central Moluccas they are called Masohi, in 
Southwest Moluccas they are called Rera or mutu. The huyula in Gorontalo means (a) Ambu: working together to keep the village or the surrounding area clean, or to solve a problem together, (b) hileiya: spontaneous help from residents when someone is in an emergency, or (c) Ti'ayo: the residents help each other with building houses, working in the fields, even preparing a wedding party (Yunus, 2014). The above mentioned local wisdom on Luang Island describes the long tradition in the life of the community and how one has taken care of one another so that the life of the community is harmonious.

The result of the interview and the observation has shown that the situation today has changed. It is the respondents aware that they have the local wisdom of the old generation have passed, why these local pearls of wisdom care is needed. Theoretically, the respondents understand the existence, the role and function of their local wisdom, and even their parents seldom practiced this in their everyday life. This means that the local wisdom is now on the sidelines and is gradually being lost. For example, on the question, whether they (the people) the old widowed or their neighbors fresh fish or bringing groceries for free like ( $t e^{\prime} w a$ and $U r$ geni), three out of 4 young people answered: no.

The changes in behavior towards local wisdom show the phenomenon of cultural change (culture shift ). On the one hand, the young people recognize the local wisdom as an integral part of the culture on the island. On the other hand, they gradually give up practicing this wisdom. In an article by Pearson Higher Education about culture and culture change, Pearson stated: "In general, the impetus for change may come from within the society or from without. From within, the unconscious or conscious pressure for consistency will produce culture change if enough people adjust old behavior and thinking to new. And change can also occur if people try to invent better ways of doing things".

The quote shows the general reasons for cultural change through conscious or unconscious pressure from the inside or from the outside of the community itself. On the other side the article argued, that the pressure of the majority can lead to opinion change. Burhanudin
(2017) also argued that the factor of the willingness of the locals to accept the new culture is also a cause of cultural change. In the globalized world, the encounter between cultures is inevitable. The rapid development of technology enables the dissemination of information through communication across territorial borders. The regular boat trips to the island can increase the mobility of people and the range of goods. The inevitable encounter between cultures as a new knowledge and perspectives leads to the mindset and the life behavior can influence. So, it cannot be ruled out that the inhabitants of Luang Island may find themselves in such a situation. It must therefore a solution in which one new cultural finds patterns of interpretation with the traditional agreed. Education and foreign language teaching can be recommended solution in this case. In general education, local wisdom can be used as teaching material at various levels. For foreign language learning, this material can be integrated into foreign language materials for tourism.

\section{The Use of local wisdom in the classroom}

One of strategies to preserve and inherit local wisdom is by integrating it into all lessons taught at school (Albantani, et all, 2018). In general, the current state of the local wisdom on the Luang island and also in Southwest Maluku brings the local district government on the idea to use the local wisdom in the school curriculum. This measure pursues the goal of introducing the local wisdom to the pupils through lessons as a kind of character formation (see Minister for school education in Indonesia 2016: 21; 2018: $379)$. It is required that every lesson plan must have three phases.

The first phase is the introduction. In this phase, the teachers activate the previous knowledge and experiences of their students with different strategies. The second is the main process. In the main process the teachers used different teaching methods. The last one is the final or evaluation phase (Minister of School Education of Indonesia 2016:21). For the establishment of local wisdom in teaching the following steps may be proposed:

1. Formulate the teaching objective

2. Identify teaching materials

3. Notice the pedagogy (teaching methods)

4. Evaluation 


\section{Lesson plan (as an example)}

Learning lessons: the students describe the local wisdom Hrukwu Mnyota

Teaching materials: term Hrukwu Mnyota, the implementation of Hrukwu Mnyota

Teaching Method: project teaching.

Evaluation: oral or written (slightly changed, see Pengembangan Pembelajaran Aktif, Pembinaan Sekolah Menengah Atas, DIRJEN Pendidikan Menengah, KEMDIKBUD, 2017).

\section{Teaching method}

1. Introduction. Activate the students' prior knowledge through key questions (W questions) or - discuss relevant video excerpts or images.

2. Main process. Form groups (3-4 people). Give work instructions. Watch Hrukwu Mnyota and the surrounding area. Collect information. Write a report. Reports present (The groups can their reports complement each other).

3. Conclusion/evaluation. The evaluation can be held orally or in writing, the learners should write or present reports based on research. As homework, each group can be assigned to collect further information about Hyoli-lieta in the community through interviews and to present it in the next class.

\section{CONCLUSION}

In the end, it can be following summarized: (a) there are several local wisdom, which the harmony of the life of the community on the Luang Island govern and the environment build may like to sample "urgeni, te'wa, hrukwu mnyota, hlili mnyota, lyola" and (b) the local wisdom have a long tradition in the community. However, this seems because of the way of life of the lost population to go, (c) The establishment of local wisdom in the classroom is a solution for maintaining the local wisdom, especially for young people. (d) Local wisdom in the Luang Island is a way to show concern for others to care for a harmonious life as a form of Kalwedo culture.

\section{REFERENCES}

Albantani, A. M., \& Madkur, A. (2018). Think globally, act locally: the strategy of in- corporating local wisdom in foreign language teaching in indonesia. International Journal of Applied Linguistics and English Literature, 7(2), 1-8.

Burhanudin, Babul, dkk., (2017): Pergeseran Budaya Remaja Suku Tengger, di Desa Argisari, Kecamatan Sanduro, Kabupaten Lumanjang. Journal of Educational Social Studies (JESS 6 (1).

Keraf, A.S. (2010). Etika Lingkungan Hidup. Jakarta : Kompas

Kurnianto, R., \& Lestarini, N. (2020, March). INTEGRATION OF LOCAL WISDOM IN EDUCATION. In INTERNATIONAL SEMINAR ON EDUCATION (pp. 557563).

Pengembangan Pembelajaran Aktif, Pembinaan Sekolah Menengah Atas, DIRJEN Pendidikan Dasar dan Menengah, KEMDIKBUD, tahun 2017.

Pearson Higher Education: Culture and Culture Change. www.pearsonhighered.com/assets/ samplechapter/0/2/0/5/0205711200.pdf

Rosidi, Ajip. (2011). Kearifan Lokal dalam Perspektif Budaya Sunda. Bandung: Kiblat Buku Utama.

Sugiyo, R., \& Purwastuti, L. A. (2017). Local wisdom-based character education model in elementary school in Bantul Yogyakarta Indonesia. Sino-US English Teaching, 14(5), 299-308.

Yunus, Rasid (2014). Nilai-Nilai Kearifan Lokal (Local Genius) Sebagai Penguat Karakter Bangsa: Studi Empiris Tentang Huyula/ oleh Rasid Yunus.--Ed.1, Cet. 1-Yogyakarta: Deepublish. 